\title{
Liquid Crystalline Mesophases of Pluronics (L64, P65, and P123) and Transition Metal Nitrate Salts $\left(\left[\mathrm{M}\left(\mathrm{H}_{2} \mathrm{O}\right)_{6}\right]\left(\mathrm{NO}_{3}\right)_{2}\right)$
}

\author{
A. Faik Demirörs, Bekir E. Eser, and Ömer Dag* \\ Bilkent University, Department of Chemistry, 06800, Ankara, Turkey
}

Received November 22, 2004. In Final Form: February 24, 2005

\begin{abstract}
The triblock poly(ethylene oxide)-poly(propylene oxide)-poly(ethylene oxide) copolymers, Pluronics (L64, P65, and P123), form liquid crystalline (LC) mesophases with transition metal nitrate salts (TMS), $\left[\mathrm{M}\left(\mathrm{H}_{2} \mathrm{O}\right)_{n}\right]\left(\mathrm{NO}_{3}\right)_{2}$, in the presence and absence of free water in the media. In this assembly process, $\mathrm{M}-\mathrm{OH}{ }_{2}$ plays an important role as observed in a TMS: $\mathrm{C}_{n} \mathrm{EO}_{m}\left(\mathrm{C}_{n} \mathrm{EO}_{m}\right.$ is oligo(ethylene oxide) nonionic surfactants) system. The structure of the LC mesophases and interactions of the metal ion-nitrate ion and metal ion-Pluronic were investigated using microscopy (POM), diffraction (XRD), and spectroscopy (FTIR and micro-Raman) techniques. The TMS:L64 system requires a shear force for mesophase ordering to be observed using X-ray diffraction. However, TMS:P65 and TMS:P123 form well structured LC mesophases. Depending on the salt/Pluronic mole ratio, hexagonal LC mesophases are observed in the TMS:P65 systems and cubic and tetragonal LC mesophases in the TMS:P123 systems. The LC mesophase in the water/salt/Pluronic system is sensitive to the concentration of free $\left(\mathrm{H}_{2} \mathrm{O}\right)$ and coordinated water $\left(\mathrm{M}-\mathrm{OH}_{2}\right)$ molecules and demonstrates structural changes. As the free water is evaporated from the $\mathrm{H}_{2} \mathrm{O}$ :TMS:Pluronic LC mesophase (ternary mixture), the nitrate ion remains free in the media. However, complete evaporation of the free water molecules enforces the coordination of the nitrate ion to the metal ion in all TMS:Pluronic systems.
\end{abstract}

\section{Introduction}

The importance of surfactant templating of inorganic solid materials was realized by the pioneering study of Kresge et al. in 1992. ${ }^{1}$ Since then there is a rapidly growing interest in surfactant templating to produce mesoporous and/or mesostructured materials. This type of templating mainly involves creating materials with desirable functions, structure, and morphology. ${ }^{2-8}$ In each of these cases, one of the key goals is to control and organize the surfactant molecules into various mesostructures. ${ }^{2-8}$

Recently, we have introduced a metallotropic liquid crystalline (LC) mesophase ${ }^{9}$ that consists of a transition metal salt $\left(\left[\mathrm{M}\left(\mathrm{H}_{2} \mathrm{O}\right)_{n}\right] \mathrm{X}_{2}\right.$ where $\mathrm{M}$ is either a first row or second row transition metal and $\mathrm{X}$ is a counteranion, such as nitrate, perchlorate, and chloride ions, represented as TMS $)$ and nonionic surfactants $\left(\mathrm{C}_{n} \mathrm{H}_{2 n+1}\left(\mathrm{CH}_{2} \mathrm{CH}_{2} \mathrm{O}\right)_{m} \mathrm{OH}\right.$, represented as $\mathrm{C}_{n} \mathrm{EO}_{m}$ ) in the presence and absence of excess water..$^{10-12}$ In the salt:surfactant systems, the coordinated water molecules and some of the counteranions undergo ligand exchange reactions and influence

* To whom correspondence should be addressed. E-mail: dag@ fen.bilkent.edu.tr. Fax: 90-312-266-4579. Tel: 90-312-266-3918.

(1) Kresge, C. T.; Leonowicz, M. E.; Roth, W. J.; Vartuli, J. C.; Beck, J. S. Nature 1992, 359, 710 .

(2) Dag, Ö.; Ozin, G. A.; Yang, H.; Reber, C.; Guillaume, B. Adv. Mater. 1999, 6, 474.

(3) Feng, X.; Fryxell, G. E.; Wang, L. Q.; Kim, A. Y.; Liu, J.; Kemner, K. M. Science 1997, 276, 923.

(4) Yang, H.; Kuperman, A.; Coombs, N.; Mamiche-Afara, S.; Ozin, G. A. Nature 1996, 379, 705 .

(5) Miyata, H.; Kuroda, K. Chem. Mater. 2000, 12, 49.

(6) Braun, P. V.; Osenar, P.; Stupp, S. I. Nature 1996, 380, 325

(7) Kimura, T.; Kamata, T.; Fuziwara, M.; Takano, Y.; Kaneda, M.; Sakamoto, Y.; Terasaki, O.; Sugahara, Y.; Kuroda, K. Angew. Chem., Int. Ed. 2000, 39, 3855 .

(8) Yang, H.; Coombs, N.; Ozin, G. A. Nature 1997, 386, 692.

(9) Çelik, Ö.; Dag, Ö. Angew. Chem., Int. Ed. 2001, 40, 3800.

(10) Dag, O..; Samarskaya, O.; Tura, C.; Günay, A.; Çelik, Ô. Langmuir 2003, 19, 3671 .

(11) Dag, Ö.; Alayoğlu, S.; Tura, C.; Çelik, Ö. Chem. Mater. 2003, 15, 2711. 8439 . the ionic strength (or ion density) of the LC media and the solubility of these salts in the nonionic surfactants.

The Hofmeister series for anions $\left(\mathrm{SO}_{4}{ }^{2-}>\mathrm{HPO}_{4}{ }^{2-}>\right.$ $\left.\mathrm{CrO}_{4}{ }^{-}>\mathrm{CO}_{3}{ }^{2-}>\mathrm{Cl}^{-}>\mathrm{Br}^{-}>\mathrm{NO}_{3}{ }^{-}>\mathrm{I}^{-}>\mathrm{ClO}_{4}{ }^{-}>\mathrm{SCN}^{-}\right)$ has been known for over a century as lyotropic (left) and hydrotropic (right) anions that influence the solubility of the surfactant molecules in a water/surfactant system. ${ }^{13,14}$ The anions on the left side make the surfactant molecules more hydrophobic, which reduces the solubility of the salts in the salt:nonionic surfactant media. However, the nitrate salts are more soluble than the perchlorate salts in the new LC system. A second parameter that is important in the new LC system is the strength of the coordination of the counteranion to the metal ion. The coordination of a nitrate ion to a metal center reduces the ionic strength (ion density) and enhances the solubility of the nitrate salts in the media. ${ }^{12}$

In the self-assembly processes, the presence of coordinated water molecules, $\left(\mathrm{M}-\mathrm{OH}_{2}\right)$, in the $\mathrm{TMS}: \mathrm{C}_{n} \mathrm{EO}_{m}$ system and hydroxide species $(\mathrm{M}-\mathrm{OH})$ in the mesostructured metal oxides is very important for organizing surfactant molecules into metallotropic mesophases through hydrogen-bonding interactions. ${ }^{9-12,15,16}$ For instance, $\mathrm{AgNO}_{3}$ cannot form an LC mesophase unless there is extra free water in the media ${ }^{10}$ and if the water evaporates or if the metal ion releases its coordinated water sphere (heating the TMS: $\mathrm{C}_{n} \mathrm{EO}_{m}$ mesophase) a semicrystalline solid $\left(\mathrm{Ag}\left(\mathrm{C}_{n} \mathrm{EO}_{m}\right)_{x} \mathrm{NO}_{3}\right)^{10}$ or a disordered gel phase $\left(\mathrm{M}\left(\mathrm{C}_{n} \mathrm{EO}_{m}\right)_{x} \mathrm{Y}_{2}\right.$, where $\mathrm{M}$ is a transition metal ion) is produced. ${ }^{12}$ However, the bivalent transition metal ions in the gel phase reabsorb the ambient water and re-form a stable LC mesophase. ${ }^{12}$

The synthesis of mesoporous silica or other metal oxides in the LC media follows a similar pattern. The hydrogen-

(13) Iwanaga, T.; Suzuki, M.; Kunieda, H. Langmuir 1998, 14, 5775.

(14) Rodriguez, C.; Kunieda, H. Langmuir 2000, 16, 8263.

(15) Crepaldi, E. L.; Grosso, D.; Soler-Illia, G. J. D. A.; Albouny, P. A.; Amenitsch, H.; Sanchez, C. Chem. Mater. 2002, 14, 3316.

(16) Dag, Ö.; Soten, I.; Çelik, Ö.; Polarz, S.; Coombs, N.; Ozin, G. A. Adv. Funct. Mater. 2003, 13, 30. 
bonding, ion-dipole, and dipole-dipole interactions between the $\mathrm{M}-\mathrm{OH}$ groups of silica or other metal oxides and the ethoxy groups of the surfactants can induce an LC mesophase during the synthesis process. The preformed LC mesophases further condense with the polymerization of the $\mathrm{M}-\mathrm{OH}$ species into mesostructured and/or mesoporous solid materials. This was first investigated by Attard et al. ${ }^{17}$ who presented the true liquid crystalline (TLC) templating of silica polymerization into mesostructured silica films and monoliths. Later, the same group, along with others, applied the TLC approach to produce mesostructured metals ${ }^{18}$ and metal sulfides. ${ }^{6,11}$

The Pluronics, $(\mathrm{PEO})_{x}(\mathrm{PPO})_{y}(\mathrm{PEO})_{x}\left(\mathrm{PEO}=-\mathrm{CH}_{2^{-}}\right.$ $\mathrm{CH}_{2} \mathrm{O}-$ ) and $\left(\mathrm{PPO}=-\mathrm{CH}\left(\mathrm{CH}_{3}\right) \mathrm{CH}_{2} \mathrm{O}-\right.$ ), also form lyotropic LC mesophases in the presence of water and with water/oil as a solvent. ${ }^{19-25}$ Many structures have been identified in the lyotropic $\mathrm{LC}$ mesophases of $\mathrm{P} 123\left(\mathrm{PEO}_{20^{-}}\right.$ $\left.\mathrm{PPO}_{70} \mathrm{PEO}_{20}\right), \mathrm{P} 105\left(\mathrm{PEO}_{37} \mathrm{PPO}_{56} \mathrm{PEO}_{37}\right)$, and $\mathrm{L} 64\left(\mathrm{PEO}_{13}-\right.$ $\left.\mathrm{PPO}_{30} \mathrm{PEO}_{13}\right) .{ }^{19-25}$ The Pluronics have also been widely used as templating agents in the synthesis of mesoporous metal oxides. ${ }^{26}$ Mesoporous materials with larger pore sizes and thicker walls have been investigated, mostly using P123. ${ }^{27-29}$

Here, we investigate the formation of the LC mesophases of the Pluronics with the TMS. The salts used in this work are mainly the first row transition metal nitrates (particularly the $\left.\left[\mathrm{Zn}\left(\mathrm{H}_{2} \mathrm{O}\right)_{6}\right] \mathrm{NO}_{3}\right)$ that have been proven to be one of the most soluble salts in the TMS: $\mathrm{C}_{n} \mathrm{EO}_{m}$ systems. The LC mesophase that will be described in this article could be used as a precursor for the synthesis of mesoporous materials with larger pores and thicker walls and for electrochemical deposition and chemical formation of nanostructured/mesostructured metals, metal oxides, and metal sulfides.

\section{Experimental Section}

Materials and Sample Preparation. The Pluronics, L64 $\left(\mathrm{PEO}_{13} \mathrm{PPO}_{30} \mathrm{PEO}_{13}, M_{\text {av }}=2900\right), \mathrm{P} 65\left(\mathrm{PEO}_{20} \mathrm{PPO}_{30} \mathrm{PEO}_{20}, M_{\text {av }}\right.$ $=3500)$, and $\mathrm{P} 123\left(\mathrm{PEO}_{20} \mathrm{PPO}_{70} \mathrm{PEO}_{20}, M_{\text {av }}=5800\right)$ are generously donated by BASF Corp. and used without further treatment. The TMSs were obtained from Aldrich and/or Fluka. The binary mixtures TMS:Pluronic were prepared by dissolving appropriate amounts of $\left[\mathrm{Zn}\left(\mathrm{H}_{2} \mathrm{O}\right)_{6}\right] \mathrm{NO}_{3}$ salts in Pluronics through several heating and cooling cycles between melting temperature and room temperature (RT). This ensures a homogeneous mixture for each composition. The ternary samples, $\mathrm{H}_{2} \mathrm{O}$ :TMS:Pluronic, were prepared by first dissolving the appropriate amount of [Zn$\left.\left(\mathrm{H}_{2} \mathrm{O}\right)_{6}\right] \mathrm{NO}_{3}$ salt in 1-3 $\mathrm{g}$ of water and then adding $1.00 \mathrm{~g}$ of Pluronic to this clear solution. The resulting mixture is homogenized by heating the mixtures to their melting point in sealed

(17) Attard, G. S.; Glyde, J. C.; Göltner, C. G. Nature 1995, 378, 366 (18) Attard, G. S.; Bartlett, P. N.; Coleman, N. R. B.; Elliott, J. M.; Owen, J. R.; Wang, J. H. Science 1997, 278, 838.

(19) Alexandridis, P.; Olsson, U.; Lindman, B. Macromolecules 1995 28,7700 .

(20) Alexandridis, P.; Zhou, D.; Khan, A. Langmuir 1996, 12, 2690

(21) Alexandridis, P.; Olsson, U.; Lindman, B. Langmuir 1998, 14, 2627.

(22) Schmidt, G.; Richtering, W.; Lindner, P.; Alexandridis, P. Macromolecules 1998, 31, 2293.

(23) Holmqvist, P.; Alexandridis, P.; Lindman, B. J. Phys. Chem. B 1998, 102, 1149

(24) Ivanova, R.; Lindman, B.; Alexandridis, P. Langmuir 2000, 16, 3660 .

(25) Zipfel, J.; Berghausen, J.; Schmidt, G.; Lindner, P.; Alexandridis,

P.; Richtering, W. Macromolecules 2002, 35, 4064.

(26) Zhao, D.; Yang, P.; Melosh, N.; Feng, J.; Chmelka, B. F.; Stucky, G. D. Adv. Mater. 1998, 10, 1380.

(27) Zhao, D.; Huo, Q.; Feng, J.; Chmelka, B. F.; Stucky, G. D. J. Am.

Chem. Soc. 1998, 120, 6024.

(28) Soler-Illia, G. J. A. A.; Crepaldi, E. L.; Grosso, D.; Sanchez, C. Curr. Opin. Colloid Interface Sci. 2003, 8, 109.

(29) Choi, S. Y.; Mamak, M.; Coombs, N.; Chopra, N.; Ozin, G. A. Adv. Funct. Mater. 2004, 14, 335. vials. Note that some samples are already liquid at this stage. Therefore homogenizing the ternary samples is a relatively easy process.

Instrumentation. The polarized optical microscopy (POM) images were obtained in transmittance mode on a Meije Techno ML9400 series polarizing microscope with transmitted light illumination, using convergent white light between the parallel and crossed polarizer. The X-ray diffraction (XRD) patterns of the LC samples, packed into 0.5 or $0.2 \mathrm{~mm}$ glass sample holders or glass plates, were recorded on a Rigaku Miniflex diffractometer using a high power $\mathrm{Cu} \mathrm{K} \alpha$ source operating at $30 \mathrm{kV} / 15 \mathrm{~mA}$. The FT-IR spectra were recorded using a Bomem Hartman MB-102 model FTIR spectrometer with a standard DTGS detector, with a resolution of $4 \mathrm{~cm}^{-1}$ and 16 or 32 scans, on thin film samples prepared on an undoped silicon wafer. The FTIR spectra of the water-containing samples were recorded by sandwiching the samples between two silicon wafers. The micro-Raman spectra were recorded on a LabRam confocal Raman microscope with a $300 \mathrm{~mm}$ focal length. The spectrometer is equipped with a HeNe laser operated at $20 \mathrm{~mW}$, polarized 500:1 with a wavelength of $632.817 \mathrm{~nm}$, and a $1024 \times 256$ element CCD camera. The signal collected was transmitted through a fiber optic cable into a grating with an $1800 \mathrm{~g} / \mathrm{mm}$ or $600 \mathrm{~g} / \mathrm{mm}$ spectrometer. The Raman spectra were collected by manually placing the probe tip near the desired point of the sample on a glass slide.

\section{Results and Discussion}

The LC mesophases of $\mathrm{L} 64\left(\mathrm{PEO}_{13} \mathrm{PPO}_{30} \mathrm{PEO}_{13}\right), \mathrm{P} 65$ $\left(\mathrm{PEO}_{20} \mathrm{PPO}_{30} \mathrm{PEO}_{20}\right)$, and $\mathrm{P} 123\left(\mathrm{PEO}_{20} \mathrm{PPO}_{70} \mathrm{PEO}_{20}\right)$ with water and water/oil are known in the literature. ${ }^{19-25}$ However, this is the first investigation in which the Pluronics show LC behavior in the presence of transition metal aqua complexes. For this, coordinated water molecules act as structure-directing agents, through hydrogenbonding with poly(ethylene oxide) (PEO) units, as demonstrated in the LC mesophases of the TMS: $\mathrm{C}_{n} \mathrm{EO}_{m}$ systems. ${ }^{9,12}$ The LC mesophases of L64, P65, and P123, using $\left[\mathrm{Zn}\left(\mathrm{H}_{2} \mathrm{O}\right)_{6}\right]\left(\mathrm{NO}_{3}\right)_{2}$ as a salt source, have been extensively investigated in various TMS/Pluronics mole ratios. This could be extended to most of the first and some of the second row transition metal nitrates, perchlorates, and some chlorides. 9,12 The LC mesophase is observed in a $\left[\mathrm{Zn}\left(\mathrm{H}_{2} \mathrm{O}\right)_{6}\right]\left(\mathrm{NO}_{3}\right)_{2}: \mathrm{L} 64$ system between 2.0 and $5.0\left[\mathrm{Zn}\left(\mathrm{H}_{2} \mathrm{O}\right)_{6}\right]\left(\mathrm{NO}_{3}\right)_{2}$ to $\mathrm{L} 64$ mole ratio (on average these mole ratios correspond to 13 and $5 \mathrm{CH}_{2} \mathrm{CH}_{2} \mathrm{O}$ units of $\mathrm{L} 64$ per $\mathrm{Zn}(\mathrm{II})$ ion or 16.5 and $33.1 \mathrm{w} / \mathrm{w} \%\left[\mathrm{Zn}\left(\mathrm{H}_{2} \mathrm{O}\right)_{6}\right]$ $\left(\mathrm{NO}_{3}\right)_{2} / \mathrm{L} 64$, respectively). The $\mathrm{LC}\left[\mathrm{Zn}\left(\mathrm{H}_{2} \mathrm{O}\right)_{6}\right]\left(\mathrm{NO}_{3}\right)_{2}: \mathrm{Plu}-$ ronic system is stable up to a mole ratio of 6 in the $\mathrm{P} 65$ and a mole ratio of 15 in the P123 systems. At high salt concentrations, the systems slowly leach the salt crystals within a few weeks. However, freshly prepared samples are homogeneous and the low and intermediate salt containing samples (salt/Pluronic mole ratio of 2-3 in L64, 2-4 in P65, and 2-7 in P123) are stable for months (no salt crystals are observed over 10 months by means of microscopy, spectroscopy, and XRD).

The mesophases of $\mathrm{H}_{2} \mathrm{O}:\left[\mathrm{Zn}\left(\mathrm{H}_{2} \mathrm{O}\right)_{6}\right]\left(\mathrm{NO}_{3}\right)_{2}$ :L64 (Figure 1) and $\mathrm{H}_{2} \mathrm{O}:\left[\mathrm{Co}\left(\mathrm{H}_{2} \mathrm{O}\right)_{6}\right]\left(\mathrm{NO}_{3}\right)_{2}: \mathrm{L} 64$ diffract at low angles; however, the diffraction line(s) eventually disappears with complete water evaporation or over time. If the $\left[\mathrm{Zn}\left(\mathrm{H}_{2} \mathrm{O}\right)_{6}\right]-$ $\left(\mathrm{NO}_{3}\right)_{2}$ or $\left[\mathrm{Co}\left(\mathrm{H}_{2} \mathrm{O}\right)_{6}\right]\left(\mathrm{NO}_{3}\right)_{2}$ salts are dissolved directly in L64 (with no extra water), the homogenized mixtures diffract again at low angles if a shear force is applied. The samples obtained after complete evaporation of the free water also show a similar response to a shear force. Therefore the LC mesophase exists both in the presence and absence of free water in the $\left[\mathrm{Zn}\left(\mathrm{H}_{2} \mathrm{O}\right)_{6}\right]\left(\mathrm{NO}_{3}\right)_{2}: \mathrm{L} 64$ systems. However, the disordered mesophase could be forced to orient by the shear forces. The mesophase of TMS:L64 is sensitive to the amount of salt and water in the mixture. It is difficult to determine the structure of 


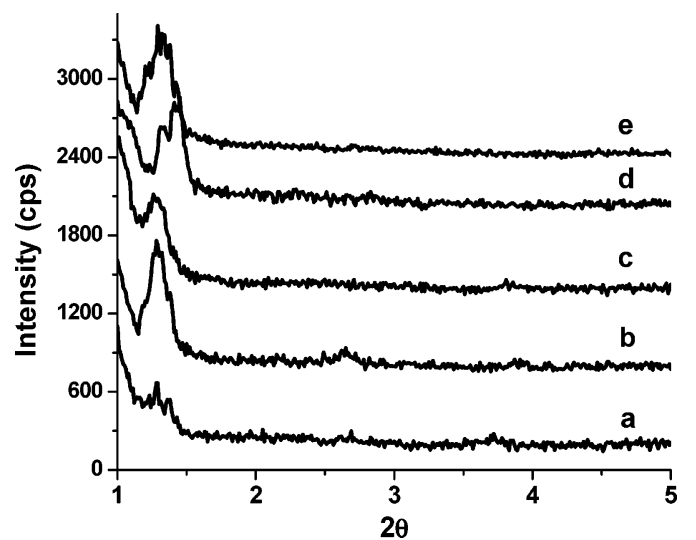

Figure 1. The XRD patterns of $\left[\mathrm{Zn}\left(\mathrm{H}_{2} \mathrm{O}\right)_{6}\right]\left(\mathrm{NO}_{3}\right)_{2}: \mathrm{L} 64$ with salt to L64 mole ratios of (a) 2.25 , (b) 2.75 , (c) 3.25 , (d) 3.75 , and (e) 4.0 .

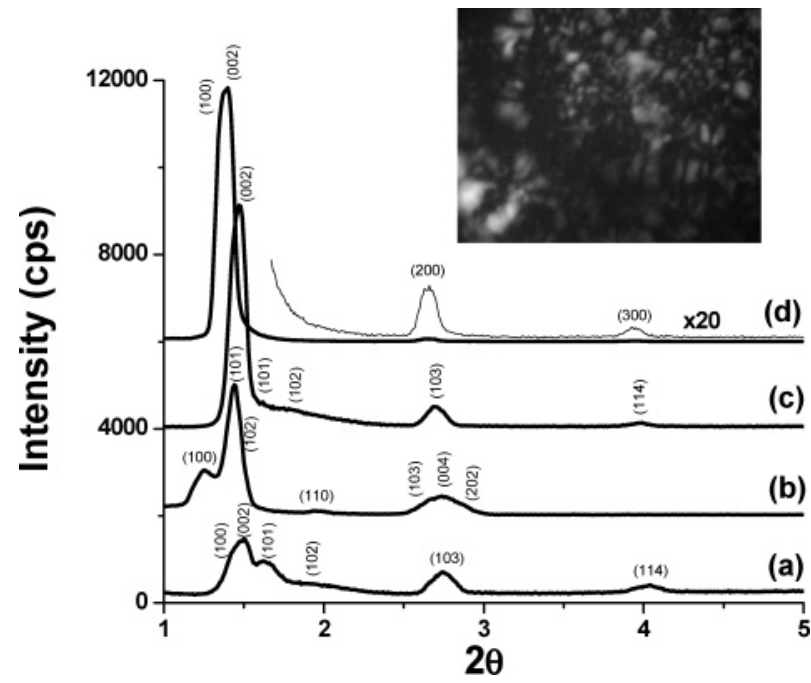

Figure 2. The XRD patterns of $\left[\mathrm{Zn}\left(\mathrm{H}_{2} \mathrm{O}\right)_{6}\right]\left(\mathrm{NO}_{3}\right)_{2}: \mathrm{P} 65$ with salt to surfactant mole ratios of (a) 3.0, (b) 4.0, (c) 5.0, and (d) 6.0 and the POM image of the sample (d).

Table 1. $d$ Spacing and $(h k l)$ Values Obtained from

Different Mole Ratios of the $\left[\mathrm{Zn}\left(\mathrm{H}_{2} \mathrm{O}\right)_{6}\right]\left(\mathrm{NO}_{3}\right)_{2}: \mathrm{P65} \mathrm{LC}$ Mesophase Using the Diffraction Patterns in Figure 2

\begin{tabular}{|c|c|c|c|c|c|c|c|}
\hline \multicolumn{2}{|c|}{3 mole ratio } & \multicolumn{2}{|c|}{4 mole ratio } & \multicolumn{2}{|c|}{5 mole ratio } & \multicolumn{2}{|c|}{6 mole ratio } \\
\hline$\overline{d(\AA)}$ & $\overline{(h k l)}$ & $\overline{d(\AA)}$ & $\overline{(h k l)}$ & $\overline{d(\AA)}$ & $\overline{(h k l)}$ & $\overline{d(\AA)}$ & $(h k l)$ \\
\hline 61.2 & $(100)$ & 69.0 & $(100)$ & 63.3 & $(100)$ & 66.3 & $(100)$ \\
\hline 58.2 & (002) & 60.9 & (101) & 59.7 & (002) & 62.6 & (002) \\
\hline 54.5 & (101) & 47.0 & (102) & 55.9 & (101) & 33.2 & (200) \\
\hline 43.0 & (102) & 40.4 & (110) & 43.5 & (102) & 22.1 & (300) \\
\hline 32.2 & (103) & 36.7 & (103) & 32.8 & (103) & & \\
\hline 22.2 & (114) & 32.8 & $(004)$ & 22.1 & (114) & & \\
\hline & & 30.9 & (202) & & & & \\
\hline
\end{tabular}

these mesophases due to the lack of higher order diffraction lines, Figure 1.

The $\left[\mathrm{Zn}\left(\mathrm{H}_{2} \mathrm{O}\right)_{6}\right]\left(\mathrm{NO}_{3}\right)_{2}: \mathrm{P} 65$ and $\left[\mathrm{Zn}\left(\mathrm{H}_{2} \mathrm{O}\right)_{6}\right]\left(\mathrm{NO}_{3}\right)_{2}: \mathrm{P} 123$ samples are more ordered and do not require shear force to be observed with XRD. The $\left[\mathrm{Zn}\left(\mathrm{H}_{2} \mathrm{O}\right)_{6}\right]\left(\mathrm{NO}_{3}\right)_{2}: \mathrm{P} 65$ samples diffract at low angles due to the mesophase in which a $3 \mathrm{D}$ hexagonal mesophase was identified using both XRD and POM. Figure 2 shows the XRD patterns of $\left.\mathrm{LC} \mathrm{Zn(}\left(\mathrm{H}_{2} \mathrm{O}\right)_{6}\right]\left(\mathrm{NO}_{3}\right)_{2}: \mathrm{P} 65$ samples with 3, 4, 5, and 6 [Zn$\left.\left(\mathrm{H}_{2} \mathrm{O}\right)_{6}\right]\left(\mathrm{NO}_{3}\right)_{2} / \mathrm{P} 65$ mole ratios in the $2 \theta$ range of $1.0-5.0^{\circ}$ and the $\mathrm{POM}$ image of $6\left[\mathrm{Zn}\left(\mathrm{H}_{2} \mathrm{O}\right)_{6}\right]\left(\mathrm{NO}_{3}\right)_{2} / \mathrm{P} 65$ mole ratios. Table 1 shows the $d$ spacing and the assigned diffraction lines from the $\left[\mathrm{Zn}\left(\mathrm{H}_{2} \mathrm{O}\right)_{6}\right]\left(\mathrm{NO}_{3}\right)_{2}: \mathrm{P} 65 \mathrm{LC}$ mesophase. The unit cell parameter $a$ varies between 70.3 and $79.7 \AA$. The $\mathrm{XRD}$ pattern of a sample with 3 mole ratio displays up to

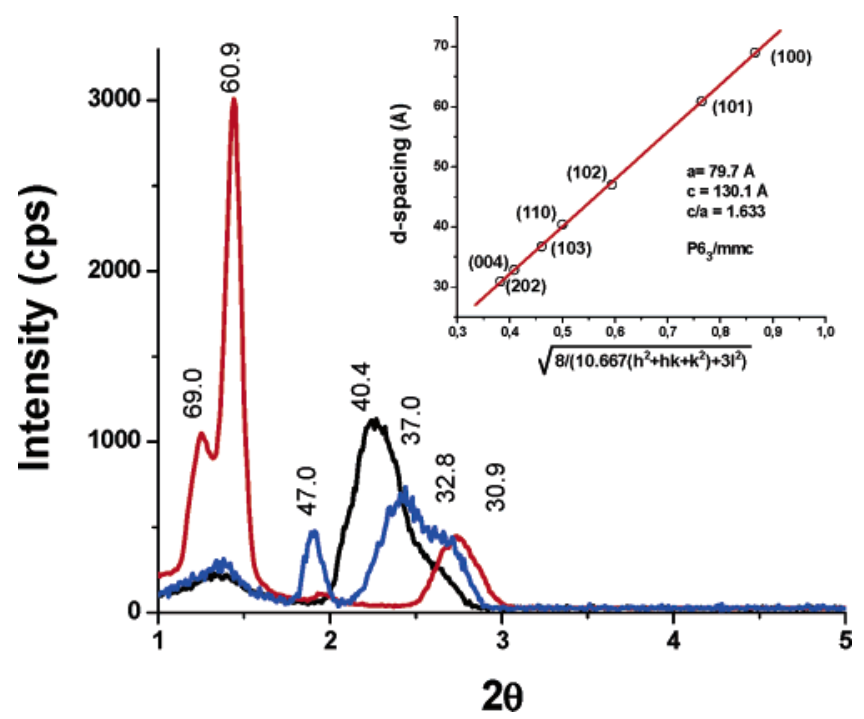

Figure 3. The XRD patterns of the $\mathrm{LC}\left[\mathrm{Zn}\left(\mathrm{H}_{2} \mathrm{O}\right)_{6}\right]\left(\mathrm{NO}_{3}\right)_{2}: \mathrm{P} 65$ system with a 4.0 mole ratio at 3 different orientations (the sample is 1 day old). The inset shows the plot of $d$ spacing versus $(h k l)$ relationship of the 3D hexagonal structure.

6 diffraction lines in the $2 \theta$ range of $1.0-5.0^{\circ}$, Figure $2 \mathrm{a}$. These lines can be indexed as the (100), (002), (101), (102), (103), and (114) reflections of the $P 6_{3} / m m c$ space group $3 \mathrm{D}$ hexagonal mesophase with unit cell parameters of $a$ $=71.2 \AA$ and $c=116.4 \AA$ with a $c / a$ ratio of 1.635 . The unit cell parameters for the other samples were also listed in Table 1. Figure 3 shows the XRD pattern of the sample with a 4 mole ratio that displays up to 7 diffraction lines. The diffraction patterns were recorded by rotating the sample in the beam-detector axis. Note that different reflections become intense at different orientations of the sample. However, all the diffraction lines can be indexed as the reflections of the 3D hexagonal mesophase. The $d$ spacing and $(h k l)$ planes are related with the following formula: $1 / d^{2}=4 / 3\left(h^{2}+h k+k^{2}\right) / a^{2}+l^{2} / c^{2}$ that could be reduced to $d=\left(8 a /\left(10.667\left(h^{2}+h k+k^{2}\right)+3 l^{2}\right)^{1 / 2}\right.$ by taking a $c / a$ ratio of 1.633 . The $d$ spacing versus $\left(8 a /\left(10.667\left(h^{2}\right.\right.\right.$ $\left.\left.+h k+k^{2}\right)+3 l^{2}\right)^{1 / 2}$ plot has a linear fit that collaborates the assumption. The hexagonal mesophase becomes highly oriented in the $6\left[\mathrm{Zn}\left(\mathrm{H}_{2} \mathrm{O}\right)_{6}\right]\left(\mathrm{NO}_{3}\right)_{2} / \mathrm{P} 65$ mole ratio. The hexagonal mesophase of the sample with a $\left[\mathrm{Zn}\left(\mathrm{H}_{2} \mathrm{O}\right)_{6}\right]-$ $\left(\mathrm{NO}_{3}\right)_{2} / \mathrm{P} 65$ mole ratio of 6 has 4 diffraction lines due to (100), (002), (200), and (300) planes with unit cell parameters $a=76.6 \AA$ and $c=125.2 \AA$ and $c / a=1.634$, Figure $2 \mathrm{~d}$. The POM image between the crossed polarizer displays a fanlike texture that is also consistent with the hexagonal mesophase, Figure 2.

The LC $\left[\mathrm{Zn}\left(\mathrm{H}_{2} \mathrm{O}\right)_{6}\right]\left(\mathrm{NO}_{3}\right)_{2}: \mathrm{P} 123$ mesophase is also sensitive to both $\left[\mathrm{Zn}\left(\mathrm{H}_{2} \mathrm{O}\right)_{6}\right]\left(\mathrm{NO}_{3}\right)_{2}$ salt and water concentration in the media. Figure 4 shows the XRD patterns of the $\mathrm{LC}\left[\mathrm{Zn}\left(\mathrm{H}_{2} \mathrm{O}\right)_{6}\right]\left(\mathrm{NO}_{3}\right)_{2}: \mathrm{P} 123$ mesophases of various mole ratios after complete water evaporation. Note that the mesophase appears at a $\left[\mathrm{Zn}\left(\mathrm{H}_{2} \mathrm{O}\right)_{6}\right]\left(\mathrm{NO}_{3}\right)_{2}$ to $\mathrm{P} 123$ mole ratio of around 2 and it is stable up to a mole ratio of 15 (not shown). In the $\mathrm{LC}\left[\mathrm{Zn}\left(\mathrm{H}_{2} \mathrm{O}\right)_{6}\right]\left(\mathrm{NO}_{3}\right)_{2}: \mathrm{P} 123$ mesophase, three different structure types, two cubic and a tetragonal mesophase, have been identified, see Figures 4-6. Figure 4 displays the XRD patterns of $\left[\mathrm{Zn}\left(\mathrm{H}_{2} \mathrm{O}\right)_{6}\right]\left(\mathrm{NO}_{3}\right)_{2}: \mathrm{P} 123$ with 4, 6, 7, and $9\left[\mathrm{Zn}\left(\mathrm{H}_{2} \mathrm{O}\right)_{6}\right]\left(\mathrm{NO}_{3}\right)_{2} / \mathrm{P} 123$ mole ratios which can be indexed to tetragonal (see also Figure 6), tetragonal, cubic, and cubic mesophases, respectively.

The complete evaporation of excess water in a disordered $\mathrm{H}_{2} \mathrm{O}:\left[\mathrm{Zn}\left(\mathrm{H}_{2} \mathrm{O}\right)_{6}\right]\left(\mathrm{NO}_{3}\right)_{2}: \mathrm{P} 123$ phase with a $\left[\mathrm{Zn}\left(\mathrm{H}_{2} \mathrm{O}\right)_{6}\right]-$ $\left(\mathrm{NO}_{3}\right)_{2} / \mathrm{P} 123$ mole ratio of 4 produces a well ordered 


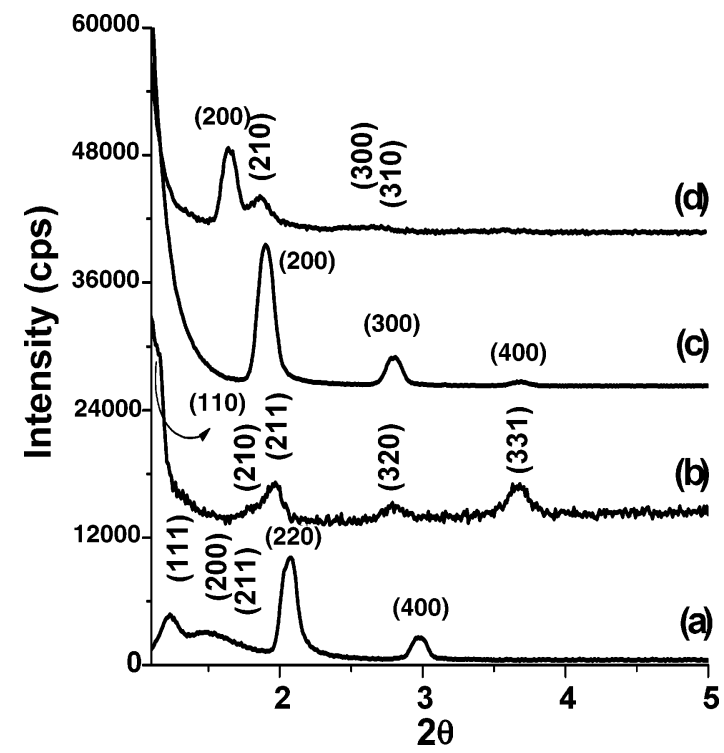

Figure 4. The XRD patterns of the $\left[\mathrm{Zn}\left(\mathrm{H}_{2} \mathrm{O}\right)_{6}\right]\left(\mathrm{NO}_{3}\right)_{2}: \mathrm{P} 123$ systems after complete water evaporation with a $\left[\mathrm{Zn}\left(\mathrm{H}_{2} \mathrm{O}\right)_{6}\right]$ $\left(\mathrm{NO}_{3}\right)_{2} / \mathrm{P} 123$ mole ratio of (a) 9.0, (b) 7.0, (c) 6.0, and (d) 4.0.

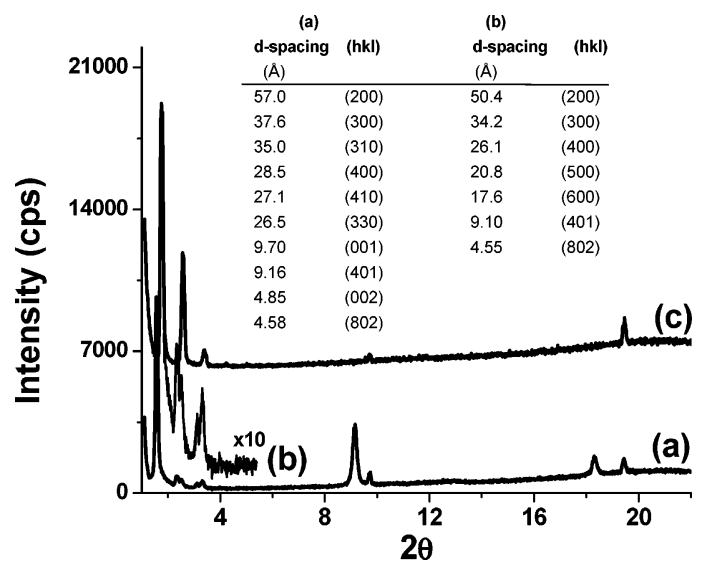

Figure 5. The XRD patterns of the $\mathrm{LC}\left[\mathrm{Zn}\left(\mathrm{H}_{2} \mathrm{O}\right)_{6}\right]\left(\mathrm{NO}_{3}\right)_{2}: \mathrm{P} 123$ systems (a) with a 5.0 salt to $\mathrm{P} 123$ mole ratio and (c) with a 6.0 salt to P123 mole ratio; (b) the same pattern as in curve a, multiplied by 10 in the region of $2.0-5.5^{\circ}$. The table in the insert shows the $d$ spacing and $(h k l)$ values evaluated from these two patterns.

tetragonal mesophase. The tetragonal mesophase has also been observed at 5 and 6 salt to P123 mole ratios, Figure 5. The low angle diffraction lines appear at an unknown water concentration and shift to higher angles with further evaporation of excess water, indicating the shrinkage of the mesophase with the removal of water in the media. Almost all excess water evaporates in 15-20 min (in thin film samples and longer in thicker samples); after that the only change in the diffraction pattern is the intensity of the diffraction lines. The $d$ spacing of the diffraction lines of the tetragonal mesophase correlates well with $1 /\left(h^{2}+k^{2}\right)^{1 / 2}$. The sample with a 4.0 mole ratio also diffracts at higher angles, between 9 and $202 \theta$. Figure 6 displays the XRD patterns that were recorded in different directions by rotating a 1 week old sample of 4.0 mole ratio in the $1-202 \theta$ range. Note that the high angle diffraction lines also respond to the rotation of the sample, indicating that these lines are also related to the oriented LC mesophase. This sample diffracts up to 8 lines at 53.8, 47.2, 35.9, 33.7, $9.7,9.1,4.84$, and $4.57 \AA d$ spacings, corresponding to (200), (210), (300), (310), (001), (401), (002), and (802) lines, respectively, Figure 6 . The unit cell parameters that are evaluated from the diffraction patterns are $a=b=106.7$ $\AA$ and $c=9.7 \AA$. The $a$ and $b$ parameters were obtained from the plot of $d$ spacing versus $1 /\left(h^{2}+k^{2}\right)^{1 / 2}$ using the (200), (210), (300), and (310) diffraction lines. The unit cell parameters indicate that there is a molecular ordering along the $c$-axis in the tetragonal mesophase, Figures 5 and 6. This indicates that the columnar tetragonal mesophase is also crystalline along the column axis. The sample with 6 mole ratio diffracts like a highly oriented lamellar mesophase (as observed from the first 5 lines) that can be indexed as the (200), (300), (400), (500), and (600) reflections with $1 / 2,1 / 3,1 / 4,1 / 5$, and $1 / 6 d$ spacing ratios, respectively. However, the diffraction lines due to (401) and (802) reflections obviously indicate a tetragonal phase. It is also important to note that smearing the sample with a glass plate by applying a weak force can destroy the orientation of the sample with a 6 salt to P65 mole ratio. The smeared sample also displays a reflection due to the (001) plane (not shown), indicating that the samples are oriented along the column axis. It is also important to note that the smeared or scratched sample (using a sharp tip) shows birefringence between the crossed polarizer indicating that the mesophase is anisotropic.

The cubic mesophase appears in a $\left[\mathrm{Zn}\left(\mathrm{H}_{2} \mathrm{O}\right)_{6}\right]\left(\mathrm{NO}_{3}\right)_{2}$ to P123 mole ratio of around 7.0 and keeps this structure at higher salt concentrations. The sample with a 7.0 mole ratio displays diffraction lines at $75,47.4,43.7,31.5$, and $24.1 \AA d$ spacings, corresponding to (110), (210), (211), (321), and (331) lines, respectively, of the $P m 3 n$ space group with a unit cell parameter $a=103.8 \AA$ that was evaluated from the slope of a plot of $d$ spacing versus $1 /\left(h^{2}\right.$ $\left.+k^{2}+l^{2}\right)^{1 / 2}$. However, at higher salt concentrations the cubic phase crystallizes into different space groups. For instance, at a 9 salt to $\mathrm{P} 123$ mole ratio, the diffraction pattern shows lines due to the (111), (200), (211), and (400) planes of the Pn3m space group at 67.7, 58.5, 47.8, and $29.2 \AA$, respectively, with a relatively larger unit cell parameter $a=117.2 \mathrm{~A}$.

A schematic representation of the tetragonal and cubic mesophase of $\left[\mathrm{Zn}\left(\mathrm{H}_{2} \mathrm{O}\right)_{6}\right]\left(\mathrm{NO}_{3}\right)_{2}: \mathrm{P} 123$ is shown in Figure 7. At higher salt concentrations, the phase becomes more disordered and it leaches out some of the salt crystals. Further studies are ongoing to elucidate the structures of a broader range of salt:Pluronic mesophases.

A 3D hexagonal mesophase is a common phase in mesostructured materials where the nonionic surfactants are used as a templating agent. ${ }^{17,27,30}$ However, the $3 \mathrm{D}$ hexagonal and a tetragonal mesophase with a well defined $c$ parameter are rare in lyotropic liquid crystalline (LLC) systems. The salt:Pluronic systems are behaving more like in the mesostructured materials, such that the $3 \mathrm{D}$ hexagonal mesophase and tetragonal mesophase could be observed from the $\left[\mathrm{Zn}\left(\mathrm{H}_{2} \mathrm{O}\right)_{6}\right]\left(\mathrm{NO}_{3}\right)_{2}: \mathrm{P} 65$ and $\left[\mathrm{Zn}\left(\mathrm{H}_{2} \mathrm{O}\right)_{6}\right]-$ $\left(\mathrm{NO}_{3}\right)_{2}: \mathrm{P} 123$ systems, respectively. Most likely, the function of metal aqua complexes in the salt:Pluronic systems is similar to silica or other metal oxide species in the true liquid crystalline templating systems of metal oxides. ${ }^{17,30,31}$ Note also that the synthesis of mesostructured silica ${ }^{30-32}$ or titania ${ }^{16}$ in the LLC mesophase of a nonionic surfactant produces an intermediate silicatropic or titaniatropic LC mesophase just before the phase becomes solid with the further polymerization of silica or titania species, respec-

(30) Dag, Ö.; Verma, A.; Ozin, G. A.; Kresge, C. T. J. Mater. Chem 1999, 9, 1475 .

(31) Samarskaya, O.; Dag, Ö. J. Colloid. Interface Sci. 2001, 238, 203.

(32) Dag, Ö.; Samarskaya, O.; Coombs, N.; Ozin, G. A. J. Mater. Chem. 2003, 13, 328. 

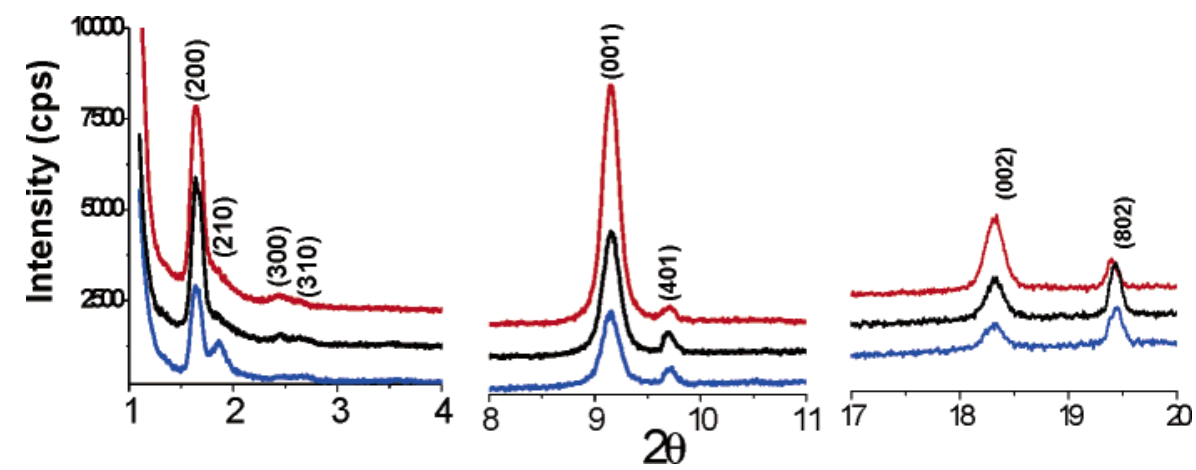

Figure 6. The XRD patterns of $4.0\left[\mathrm{Zn}\left(\mathrm{H}_{2} \mathrm{O}\right)_{6}\right]\left(\mathrm{NO}_{3}\right)_{2}: \mathrm{P} 123$ after 1 week of water evaporation, measured in different orientations: (top) rotated to right, (middle) as packed, and (bottom) rotated left with respect to the beam-detector axis.

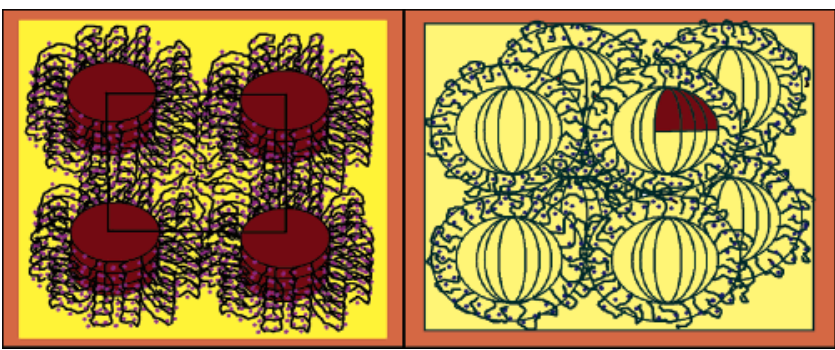

Figure 7. Schematic representation of the $\left[\mathrm{Zn}\left(\mathrm{H}_{2} \mathrm{O}\right)_{6}\right]\left(\mathrm{NO}_{3}\right)_{2}$ : P123 mesophases (left is the tetragonal and right is the cubic mesophases); small dots represent the ions in the media, hairy parts represent $\mathrm{PEO}$, and the dark red parts represent the PPO units of P123.

tively. The salt:Pluronic systems could be categorized in the same group as silicatropic ${ }^{30-32}$ or titanotropic ${ }^{16}$ LC mesophases.

The water evaporation process and thermal behavior of the $\mathrm{LC} \mathrm{H}_{2} \mathrm{O}:\left[\mathrm{Zn}\left(\mathrm{H}_{2} \mathrm{O}\right)_{6}\right]\left(\mathrm{NO}_{3}\right)_{2}$ :Pluronic and $\left[\mathrm{Zn}\left(\mathrm{H}_{2} \mathrm{O}\right)_{6}\right]$ $\left(\mathrm{NO}_{3}\right)_{2}$ :Pluronic systems have also been investigated using FTIR, micro-Raman spectroscopy, and XRD methods, Figures 8-10, respectively, using the same samples for each measurement. The nitrate ion in the $\left[\mathrm{Zn}\left(\mathrm{H}_{2} \mathrm{O}\right)_{6}\right]$ $\left(\mathrm{NO}_{3}\right)_{2}$ :Pluronic systems coordinates to the metal ion through a ligand exchange mechanism. ${ }^{12}$ With the evaporation of free water molecules in the LC media, the IR peaks due to the asymmetric stretching modes of the coordinated nitrate ion at 1285 and $1490 \mathrm{~cm}^{-1}$ appear and dominate the spectra, Figure 8 . Note that the free nitrate ion has a doubly degenerate asymmetric stretching mode at around $1360 \mathrm{~cm}^{-1}$ that splits into two nondegenerate modes upon coordination (symmetry of the free nitrate ion is lowered from $D_{3 h}$ to $C_{2 v}$ upon coordination). ${ }^{10}$ The $\mathrm{Zn}-\mathrm{ONO}_{2}$ coordination could also be realized from the deformation modes at around $800-830 \mathrm{~cm}^{-1}$ and the inactive symmetric stretching mode (it becomes active upon coordination) observed at $1030 \mathrm{~cm}^{-1}$ of the coordinated nitrate ion. ${ }^{10}$ For comparison purposes, Figure 8A shows the IR spectra of the pure L64, P65, and P123 with those of water-free samples of $\left[\mathrm{Zn}\left(\mathrm{H}_{2} \mathrm{O}\right)_{6}\right]\left(\mathrm{NO}_{3}\right)_{2}: \mathrm{L} 64$, [Zn$\left.\left(\mathrm{H}_{2} \mathrm{O}\right)_{6}\right]\left(\mathrm{NO}_{3}\right)_{2}: \mathrm{P} 65$, and $\left[\mathrm{Zn}\left(\mathrm{H}_{2} \mathrm{O}\right)_{6}\right]\left(\mathrm{NO}_{3}\right)_{2}: \mathrm{P} 123$. Note that major changes are taking place in the $\mathrm{NO}_{3}{ }^{-}$related peaks and some minor changes in the Pluronics regions, indicating that the Pluronics also undergo conformational changes, going from pure to salted Pluronics. The $\mathrm{C}-\mathrm{O}$ stretching region of the Pluronics shifts to lower energy in the salted systems indicating a hydrogen-bonding interaction between the ethoxy groups of the Pluronics and coordinated water molecules of metal ions $(\mathrm{M}-$ $\left.\mathrm{O}(\mathrm{H}) \mathrm{H}-\mathrm{-}^{-} \mathrm{O}\left(\mathrm{CH}_{2} \mathrm{CH}_{2}\right)_{2}\right)$. Similarly the Raman active symmetric stretching mode at around $1056 \mathrm{~cm}^{-1}$ of the free nitrate ion shifts to $1030 \mathrm{~cm}^{-1}$ upon coordination,

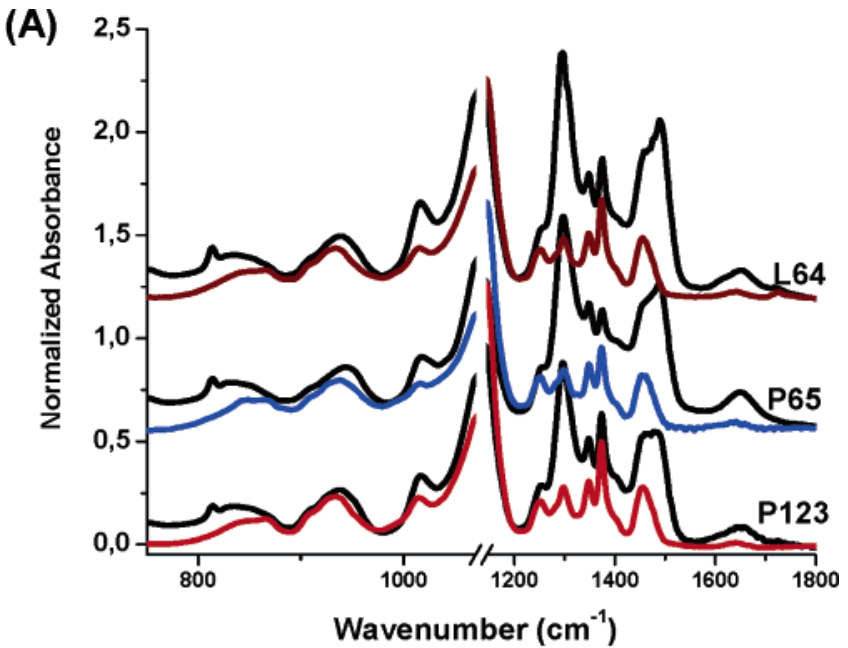

(B)
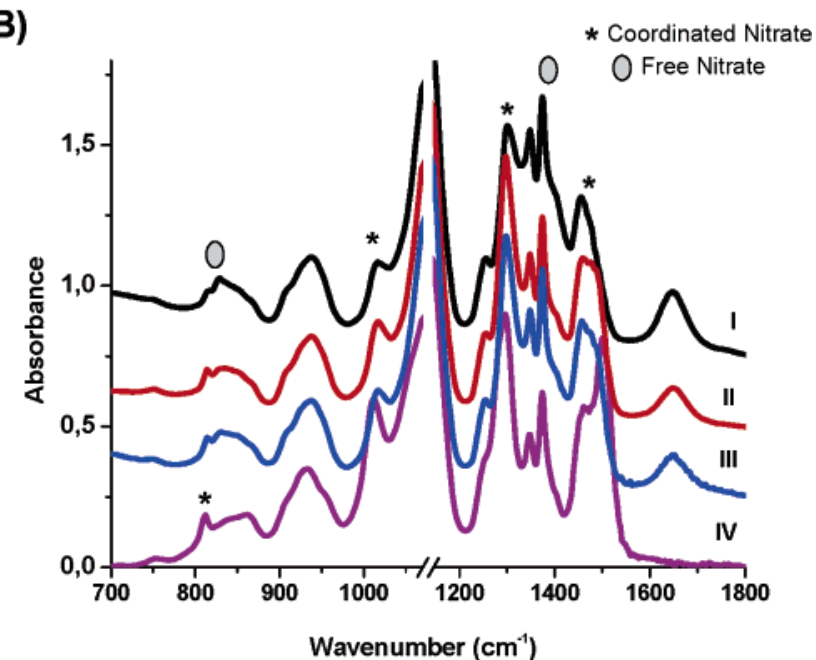

Figure 8. (A) FTIR spectra of $\left[\mathrm{Zn}\left(\mathrm{H}_{2} \mathrm{O}\right)_{6}\right]\left(\mathrm{NO}_{3}\right)_{2}: \mathrm{L} 64$ and $\mathrm{L} 64$ (top), $\left[\mathrm{Zn}\left(\mathrm{H}_{2} \mathrm{O}\right)_{6}\right]\left(\mathrm{NO}_{3}\right)_{2}: \mathrm{P} 65$ and $\mathrm{P} 65$ (middle), and $\left[\mathrm{Zn}\left(\mathrm{H}_{2} \mathrm{O}\right)_{6}\right]-$ $\left(\mathrm{NO}_{3}\right)_{2}: \mathrm{P} 123$ and P123 (bottom) with the same salt/Pluronic mole ratios (the $\mathrm{Zn}(\mathrm{II}) / \mathrm{PEO}$ ratio was 6.15 in all samples). (B) FTIR spectral changes with the evaporation of water from the $\left[\mathrm{Zn}\left(\mathrm{H}_{2} \mathrm{O}\right)_{6}\right]\left(\mathrm{NO}_{3}\right)_{2}: \mathrm{P} 123$ system with a 5.0 mole ratio (I) immediately after sample preparation, (II) after equilibrium at $\mathrm{RT}$, (IV) heated at $100{ }^{\circ} \mathrm{C}$, and (III) cooled to RT.

Figure 9 . This peak is very sensitive to the water content of the media. If the water is completely removed from the mixture, the peak at $1056 \mathrm{~cm}^{-1}$ almost disappears (not shown), indicating that all the nitrate ions in the media are coordinated to the metal ion. At equilibrium the nitrate ions are in coordinated ion $\left(\mathrm{M}-\mathrm{O}_{2} \mathrm{NO}\right.$ or $\left.\mathrm{M}-\mathrm{ONO}_{2}\right)$ and/ or free ion $\left(\mathrm{NO}_{3}{ }^{-}\right)$states. Further studies are required to elucidate the conformational changes in the Pluronics to 


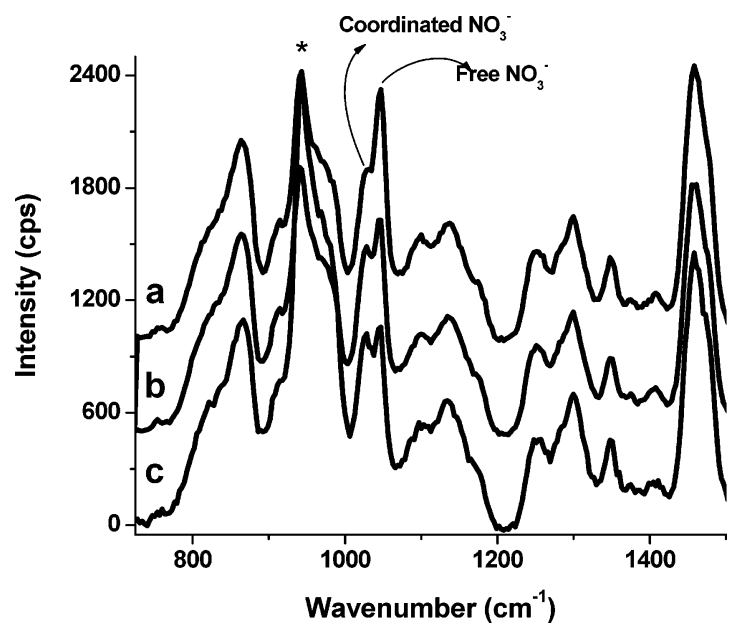

Figure 9. The micro-Raman spectra of $\left[\mathrm{Zn}\left(\mathrm{H}_{2} \mathrm{O}\right)_{6}\right]\left(\mathrm{NO}_{3}\right)_{2}: \mathrm{P} 123$ with a 6.15 salt to surfactant mole ratio, before (a) and after (b) equilibrium at $\mathrm{RT}$ and heated $\left(100^{\circ} \mathrm{C}\right)$ and cooled sample (c) in Figure 8.

better understand the structural properties of the saltinduced LC mesophases of this kind.

We further investigated the $\left[\mathrm{Zn}\left(\mathrm{H}_{2} \mathrm{O}\right)_{6}\right]\left(\mathrm{NO}_{3}\right)_{2}: \mathrm{P} 65$ and $\left[\mathrm{Zn}\left(\mathrm{H}_{2} \mathrm{O}\right)_{6}\right]\left(\mathrm{NO}_{3}\right)_{2}: \mathrm{P} 123$ mesophases by first evaporating excess water at RT and then heating the samples between $\mathrm{RT}$ and $100^{\circ} \mathrm{C}$ using FTIR and micro-Raman spectroscopy and XRD techniques. The peaks, due to the coordinated nitrate ion at 1296 and $1496 \mathrm{~cm}^{-1}$ in the IR spectra, gain intensity while the free nitrate ion signal at around 1360 $\mathrm{cm}^{-1}$ is losing its intensity during the evaporation and heating processes, Figure $8 \mathrm{~B}$. Heating the $\left[\mathrm{Zn}\left(\mathrm{H}_{2} \mathrm{O}\right)_{6}\right]$ $\left(\mathrm{NO}_{3}\right)_{2}$ :Pluronics changes the equilibrium conditions between the free and coordinated nitrate ions in favor of the coordinated nitrate ion in the media. However, cooling the sample restores the equilibrium spectrum that is comparable to the spectrum before heating over a $1 \mathrm{~h}$ to a 1 day period, depending on the number of PPO units in the Pluronics (slow in P123 and fast in P65) systems. Heating definitely shifts the equilibrium reaction (eq 1) in favor of coordination. The IR and Raman spectral changes suggest that complete water evaporation, removing coordinated water molecules, yields an intermediate complex in which both nitrate ions are coordinated. However, this complex is not stable and upon adsorption of ambient water, it decomposes into equilibrium species. The adsorption of water is almost immediate in P65 and L64, but it takes several days in the case of P123.

$$
\begin{aligned}
& {\left[\mathrm{M}\left(\mathrm{H}_{2} \mathrm{O}\right)_{n}\right]^{2+}+2 \mathrm{NO}_{3}{ }^{-} \rightleftharpoons} \\
& \quad\left[\mathrm{M}\left(\mathrm{H}_{2} \mathrm{O}\right)_{n-x}\left(\mathrm{O}_{2} \mathrm{NO}\right)_{x}\right]+x \mathrm{H}_{2} \mathrm{O}+2-x \mathrm{NO}_{3}{ }^{-}
\end{aligned}
$$

Evaporation and heating trends were also followed using the XRD method. The mixture of $\mathrm{H}_{2} \mathrm{O}$ : $\left[\mathrm{Zn}\left(\mathrm{H}_{2} \mathrm{O}\right)_{6}\right]\left(\mathrm{NO}_{3}\right)_{2}$ : $\mathrm{P} 123$ with a 7.0 mole ratio is liquid up to the removal of a certain amount of water (see the first diffraction pattern, curve a in Figure 10A). The $\left.\mathrm{LC} \mathrm{Zn}\left(\mathrm{H}_{2} \mathrm{O}\right)_{6}\right]\left(\mathrm{NO}_{3}\right)_{2}: \mathrm{P} 123$ mesophase gets oriented upon the removal of excess water. The XRD pattern displays two intense diffraction lines at 75 and $44 \AA$ due to the (110) and (211) planes of the cubic phase. However, heating and cooling the samples disrupts the orientation providing higher order diffraction lines. The heated and cooled samples display up to 5 diffraction lines at $75,47.4,43.7,31.5$, and $24.1 \AA d$ spacing, corresponding to the (110), (210), (211), (320), and (331) planes, respectively, Figure 10A. The structure of the mesophase is most likely the same before and after the heating and cooling cycles.
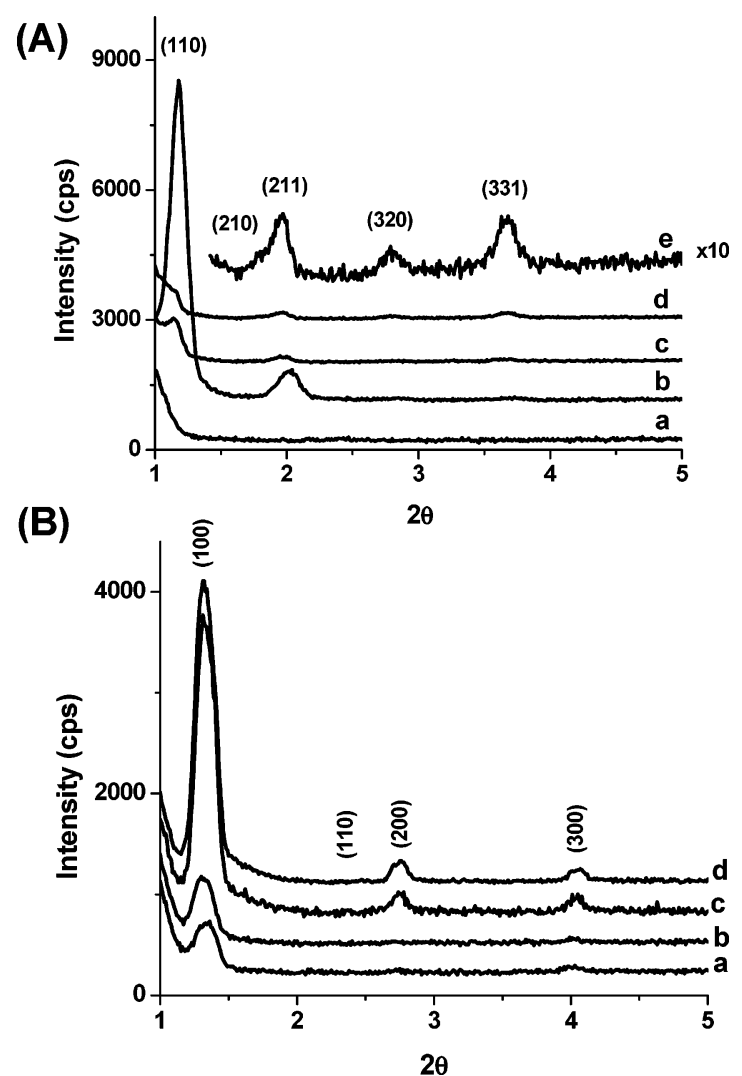

Figure 10. The XRD patterns of (A) $\mathrm{H}_{2} \mathrm{O}:\left[\mathrm{Zn}\left(\mathrm{H}_{2} \mathrm{O}\right)_{6}\right]\left(\mathrm{NO}_{3}\right)_{2}$ : $\mathrm{P} 123$ with a 7.0 mole ratio: (a) before water evaporation, (b) $1 \mathrm{~h}$ after water evaporation at RT, (c) heated sample at around $100{ }^{\circ} \mathrm{C}$, (d) kept at RT for $1 \mathrm{~h}$ after, (e) $\times 10$ of curve d. (B) $\mathrm{H}_{2} \mathrm{O}:\left[\mathrm{Zn}\left(\mathrm{H}_{2} \mathrm{O}\right)_{6}\right]\left(\mathrm{NO}_{3}\right)_{2}: \mathrm{P} 65$ with a mole ratio is 4.0 : (a) immediately after the phase appears upon water evaporation, (b) after $1 \mathrm{~h}$ of water evaporation, (c) sample b heated a few minutes for complete water evaporation on a hot plate and cooled to RT, and (d) $1 \mathrm{~h}$ cooling of sample c.

The XRD pattern of the $\mathrm{LC}\left[\mathrm{Zn}\left(\mathrm{H}_{2} \mathrm{O}\right)_{6}\right]\left(\mathrm{NO}_{3}\right)_{2}: \mathrm{P} 65$ mesophase upon heating and cooling follows a different behavior. In the $\left[\mathrm{Zn}\left(\mathrm{H}_{2} \mathrm{O}\right)_{6}\right]\left(\mathrm{NO}_{3}\right)_{2}$ :P65 system, the evaporation of free water leads to an $\mathrm{LC}$ mesophase that becomes more oriented upon heating and cooling, Figure 10B. Heating the $\left[\mathrm{Zn}\left(\mathrm{H}_{2} \mathrm{O}\right)_{6}\right]\left(\mathrm{NO}_{3}\right)_{2}: \mathrm{P} 65$ mesophase with a mole ratio of 4 causes further orientation of the mesophase where the intensities of the diffraction lines increase by 5 -fold. On the other hand, heating and cooling reduces the unit cell parameters; however it does not disturb the structure of the LC mesophase, Figure 10B.

The $\mathrm{H}_{2} \mathrm{O}:\left[\mathrm{Zn}\left(\mathrm{H}_{2} \mathrm{O}\right)_{6}\right]\left(\mathrm{NO}_{3}\right)_{2}: \mathrm{L} 64$ becomes ordered with the evaporation of some water, but complete water evaporation makes the phase disordered. It is difficult to identify the structure of the $\mathrm{LC}\left[\mathrm{Zn}\left(\mathrm{H}_{2} \mathrm{O}\right)_{6}\right]\left(\mathrm{NO}_{3}\right)_{2}: \mathrm{L} 64$ mesophases. Further studies are ongoing to elucidate the structural and thermal behavior of the TMS:Pluronic systems.

In all assembly processes discussed in this work, the coordinated water-ethoxy interaction plays a key role. The metal and nitrate ions are distributed in the hydrophilic domains of the LC media. The increase in the ion density (by increasing salt concentration or keeping the ions free in the media) of the media forces the mesophase to undergo phase changes to increase its hydrophilic free volume to accommodate the ions in the hydrophilic domains of the mesophase. The observed changes from $3 \mathrm{D}$ hexagonal to $2 \mathrm{D}$ hexagonal mesophase with decreasing water content in the P65 and the changes from tetragonal 
to cubic with increasing salt concentrations in the P123 are indirect measures for the above proposal.

The rigidity of the structure is related to the degree of the hydrophobic character and also the mass of the surfactant molecules. The P123 is the heaviest and most hydrophobic (the $\mathrm{PPO} / \mathrm{PEO}$ ratio is the largest) among the three Pluronics with the richest structural diversity. This diversity is most likely driven by the balance between the hydrophilic and hydrophobic forces in the mesophases. The smallest number of EO groups that accommodate a metal ion is in the range of $2.5-3$ in the $\mathrm{P} 123$ and $6.5-7$ in the P65 and L64 systems. Note also that the number of EO units in both P65 and P123 and the PO units in the P65 and L64 are on average the same. Therefore, within the first approximation, one could list the P123 as the least hydrophilic, then L64, and then P65. However, the solubility of $\left[\mathrm{Zn}\left(\mathrm{H}_{2} \mathrm{O}\right)_{6}\right]\left(\mathrm{NO}_{3}\right)_{2}$ in $\mathrm{P} 123$ is the highest; therefore the salt ions, $\mathrm{Zn}$ (II) and nitrate, in the media influence the hydrophilicity of the surfactant molecules. Since the nitrate ion is known as one of the hydrotropic anions in the Hofmeister series, it enhances the hydrophilicity of the Pluronics in the systems with high salt concentrations.

In future experiments, other salts, such as $\left[\mathrm{Zn}\left(\mathrm{H}_{2} \mathrm{O}\right)_{6}\right]$ $\left(\mathrm{ClO}_{4}\right)_{2}$ and $\left[\mathrm{Zn}\left(\mathrm{H}_{2} \mathrm{O}\right)_{6}\right] \mathrm{Cl}_{2}$, will be used to answer some of the questions raised in this work. However, this is the first example of a LC TMS:Pluronic system in which the structure of the mesophase could be controlled by playing with either the hydrophilicity of the Pluronic or the salt concentration of the media.

\section{Conclusion}

The TMS(s) dissolves in the triblock Pluronic copolymers and produces LC mesophases. In this, the interactions of the coordinated water molecules and ethoxy groups of the PEO units $\left(\mathrm{M}-\mathrm{OH}_{2}---\mathrm{OCH}_{2} \mathrm{CH}_{2}-\right)$, through hydrogenbonding, and nitrate ion with the metal ion $\left(\mathrm{M}-\mathrm{O}_{2} \mathrm{NO}\right)$, through coordination, stabilize the LC mesophase into a different structure type. In the TMS:L64 system, the mesophase is quite disordered; however, the TMS:P65 and TMS:P123 systems are ordered and well structured. The $\mathrm{H}_{2} \mathrm{O}$ :TMS:Pluronic systems are sensitive to the water content of the media and undergo structural changes by the evaporation of excess water in the media. The hexagonal mesophase in the $\left[\mathrm{Zn}\left(\mathrm{H}_{2} \mathrm{O}\right)_{6}\right]\left(\mathrm{NO}_{3}\right)_{2}$ :P65 systems and the tetragonal and cubic LC mesophases in the $\left[\mathrm{Zn}\left(\mathrm{H}_{2} \mathrm{O}\right)_{6}\right]\left(\mathrm{NO}_{3}\right)_{2}: \mathrm{P} 123$ systems were identified. The [Zn$\left.\left(\mathrm{H}_{2} \mathrm{O}\right)_{6}\right]\left(\mathrm{NO}_{3}\right)_{2}: \mathrm{P} 123$ mesophase is sensitive to the salt concentration, which can be increased up to a 15 mole ratio (it corresponds to ca. $42.6 \mathrm{w} / \mathrm{w} \%$ and $2.67 \mathrm{EO} / \mathrm{Zn}-$ (II)). The LC mesophase obtained from the salt:Pluronic system could be used as a reaction medium to produce mesostructured materials.

Acknowledgment. For financial support, Ö.D. gratefully acknowledges the Scientific and Technical Research Council of Turkey (TÜBİTAK) in the framework of the project TBAG-2263 (102T188) and the Turkish Academy of Science in the framework of a Young Scientist Award (ÖD/TÜBA-GEBİP/2002-1-6).

LA047136L 